\title{
ДО ПИТАННЯ СПІВВІДНОШЕННЯ ГРОМАДЯНСЬКОГО І ПАТРІОТИЧНОГО ВИХОВАННЯ
}

У статті розглянуто сутність поняття «патріотичне виховання» та його завдання, згідно сучасної системи національно-патріотичного виховання; визначено феномен громадянського виховання та його компоненти; за допомогою методів аналізу, синтезу, доведення, порівняння, абстрагування, узагальнення, конкретизації співвіднесено поняття «громадянське виховання» та «патріотичне виховання».

Ключові слова: патріотичне виховання; громадянське виховання; вищий військовий навчальний заклад; иіннісне ставлення до себе; иіннісне ставлення до інших; иүіннісне ставлення до Батьківщини; изіннісне ставлення до праці; політична $i$ правова культура.

Постановка проблеми. В умовах російської агресії, тимчасової окупації автономної республіки Крим, окремих районів Луганської та Донецької областей, поруч з питаннями обороноздатності нашої держави та готовності українців ставати на захист рідної землі, особливого звучання набуває питання патріотичного виховання дітей і молоді.

Починаючи з періоду здобуття Україною незалежності, вийшла ціла низка концепцій національного виховання, де здійснювалися спроби окреслити виховний вектор для українських педагогів. Справжнім проривом була «Концепція громадянського виховання» за авторства К.І. Чорної, О.В. Сухомлинської, М.Й. Боришевського, І.Г. Гараненка, С.Г. Рябова, затверджена у 2000 році. Вагомими в організації виховного процесу загальних середніх закладів та закладів вищої освіти $є$ такі документи як Концепція національно-патріотичного виховання молоді, затверджена 27.10.2009, Концепція національного виховання студентської молоді, затверджена 16.06.2015.

Аналіз останніх досліджень і публікацій. Питання патріотичного виховання в умовах вищого військового навчального закладу вивчали В.Ю. Артемов, В.Ф. Баранівський, В.К. Майборода, В.М. Манько, Б.О. Пантюхов, О.І. Покотило, О.О. Салата, О.Л. Скрябін, О.В. Тарасенко та інші дослідники. Особливий науковий інтерес становить дисертаційне дослідження О.О. Пашкової «Військово-патріотичне виховання курсантів вищих військових навчальних закладів України (1991-2019)» [3], в якому узагальнено досвід військово-патріотичного виховання курсантів вищих військових навчальних закладів періоду незалежності та запропоновано рекомендації щодо використання воєнно-історичних знань у процесі військово-патріотичного виховання майбутніх офіцерів Збройних Сил 
України. Проте питання співвідношення патріотичного і громадянського виховання потребують подальшого дослідження.

Мета статті - визначити співвідношення понять «патріотичне виховання» $\mathrm{i}$ «громадянське виховання».

Методи дослідження. У ході дослідження було використано методи аналізу, синтезу, доведення, порівняння, абстрагування, узагальнення, конкретизації з метою об' єктивного вивчення феноменів патріотичного та громадянського виховання.

Виклад основного матеріалу. Міністерство освіти і науки дає роз'яснення щодо сучасної системи національно-патріотичного виховання: «Національнопатріотичне виховання дітей та молоді - це комплексна системна i цілеспрямована діяльність органів державної влади, освітніх закладів, громадських організацій, сім'ї та інших соціальних інститутів щодо формування у молодого покоління високої патріотичної свідомості, почуття вірності, любові до Батьківщини, турботи про благо свого народу, готовності до виконання громадянського і конституційного обов'язку із захисту національних інтересів, цілісності, незалежності України, сприяння становленню ii як правової, демократичної, соціальної держави. Найважливішим пріоритетом національно-патріотичного виховання $\epsilon$ формування ціннісного ставлення особистості до українського народу, Батьківщини, держави, нації» [2].

Мета патріотичного виховання конкретизується через систему таких виховних завдань: утвердження в свідомості i почуттях особистості патріотичних цінностей, переконань і поваги до культурного та історичного минулого України; виховання поваги до Конституції України, законів України, державної символіки; підвищення престижу військової служби, а звідси культивування ставлення до солдата як до захисника вітчизни, героя; усвідомлення взаємозв' язку між індивідуальною свободою, правами людини та iii патріотичною відповідальністю; сприяння набуттю дітьми та молоддю патріотичного досвіду на основі готовності до участі в процесах державотворення, уміння визначати форми та способи своєї участі в життєдіяльності громадянського суспільства, спілкуватися 3 соціальними інститутами, органами влади, спроможності дотримуватись законів та захищати права людини, готовності взяти на себе відповідальність, здатності розв'язувати конфлікти відповідно до демократичних принципів; формування толерантного ставлення до інших народів, культур і традицій; утвердження гуманістичної моральності як базової основи громадянського суспільства; культивування кращих рис української ментальності: працелюбності, свободи, справедливості, доброти, чесності, бережного ставлення до природи; формування мовленнєвої культури; спонукання зростаючої особистості до активної протидії українофобству, аморальності, сепаратизму, шовінізму, фашизму.

Проте значення громадянського виховання значно ширше. Крім того, воно обернене до особистості громадянина. Адже в його основі покладено ідею Ж. - Ж. Руссо про принцип природнього права, коли права людини на гідне життя, роботу, умови для вдосконалення вище від людських законів. А отже держава забезпечує гідні умови спершу, а потім вимагає відданості, дотримання 
законів, служіння народу, і здатність віддати життя за співвітчизників, що називається патріотизмом.

Крім того, громадянське виховання передбачає знання своїх прав і свобод та вміння їх захистити у цивілізований спосіб, повагу до гербу, гімну, символіки, знання рідної історії та культури і їх шанування.

На думку авторів «Концепції громадянського виховання», громадянське виховання - процес формування громадянськості як інтегрованої якості особистості, що надає людині можливість відчувати себе морально, соціально, політично, юридично дієздатною та захищеною. Воно покликане виховувати особистість чутливою до свого оточення, долучати іiі до суспільного життя, в якому права людини виступають визначальними. Громадянське виховання об'єднує в собі суспільну й приватну сфери.

Звідси громадянськість - багатоаспектне поняття. Це фундаментальна духовно-моральна якість, світоглядно-психологічна характеристика особистості, що має культурологічні засади. Громадянськість - це також реальна можливість втілення в життя сукупності соціальних, політичних i громадянських прав особистості, її інтеграція в культурні й соціальні структури суспільства.

В педагогічному плані громадянськість містить в собі знання, переживання й вчинки. Ці складові знаходяться в певних зв’язках й взаємодії при переважанні на певних етапах розвитку індивіда емоційного компоненту, формування почуттєвої сфери [1].

Мета громадянського виховання реалізується через визнання й забезпечення в реальному житті прав людини як гуманістичної цінності та єдиної норми всіх людей без будь-яких дискримінацій, на чому будується відкрите, демократичне, громадянське суспільство; зв'язок прав людини із іiі громадянською відповідальністю; формування національної свідомості, належності до рідної землі, народу; утвердження гуманістичної моралі та формування поваги до таких цінностей як свобода, рівність, справедливість; формування соціальної активності особистості; формування працелюбності особистості, відповідальності за свої дії; формування політичної та правової культури; виховання поваги до Конституції України, законодавства, державної мови; розвиток критичного мислення; формування інтеркультурного менталітету; вироблення негативного ставлення до будь-яких форм насильства; активне попередження тенденцій до виявлення деструктивного націоналізму, проявів шовінізму, фашизму, месіанських налаштованостей.

Поняття громадянського виховання ми розуміємо у зв'язку понять ціннісне ставлення до себе - до інших - до Батьківщини.

Ціннісні ставлення грунтуються на гуманістичних принципах і виконують роль регулятора у відносинах між особистістю та існуючою дійсністю.

У виховній практиці радянського періоду пропагувалась сліпа любов Вітчизни, що передбачала повне самозречення. На жаль, сьогодні ми маємо суспільство людей, які не вірять ні у потенціал своєї держави, ні в теперішнє, ні у свої сили. В той час, коли психолого-педагогічною практикою доведено: людина, яка не може любити себе, не здатна любити 
інших людей, адже вона просто не вміє відчувати, а значить і виявляти це почуття.

Під любов'ю до себе ми розуміємо ціннісне ставлення до своїх інтересів, потреб, думок, переживань, діяльності, - до всього, що пов'язане 3 формуванням власної особистості. Це не самозадоволення, а постійний творчий пошук себе кращого, віра у свої сили.

Ціннісно ставитися до власної особистості означає приймати себе, цінувати свої якості. Приймаючи себе, людина не лише приділяє увагу своїм позитивним рисам. Вона визнає власні недоліки, визначає засоби їх подолання, тобто обирає конструктивний шлях саморозвитку. I перша сходинка до змін вміння виділити ті якості, що тї не задовольняють. Людину можуть не влаштовувати певні риси, вчинки, але вона повинна приймати себе в цілому, не ототожнюючи власне "Я" зі своєю поведінкою, вадами, адже “образ я" - це ядро особистості.

Ціннісне ставлення до себе формується завдяки внутрішній свободі, відкритості до навколишньої дійсності та процесам самопізнання i самоусвідомлення. Велику роль у процесі формування ціннісного ставлення до себе відіграє особиста гідність як основа розуміння свого місця у суспільстві та усвідомлення громадського обов'язку.

Завдання, яке постало сьогодні перед педагогами, психологами, вихователями, - допомогти особистості пізнати та прийняти своє “Я”. I це прийняття навчить цінувати не лише свій внутрішній світ, але й світ іншої людини, що безпосередньо пов’язано з ціннісним ставленням до Батьківщини і людства в цілому.

Ціннісне ставлення до інших усвідомлюється нами як повага до внутрішнього світу, дій, вчинків, думок людей, які знаходяться поруч. Особистість, що ціннісно ставиться до інших, не здатна на злочин, підлість, зраду, брехню, адже їі повага до людей не дозволить вчинити подібне.

Але ціннісне ставлення до інших передбачає не тільки повагу до думок людей, але й передбачає проникнення до сфери їх почуттів, здатність поставити себе на місце іншого, емоційний відгук на його переживання.

Ціннісне ставлення до себе та до інших реалізується завдяки положенню "Я - індивідуальність у системі інших індивідуальностей". Інтерес до себе як до особистості повинен поширюватися і на людей, які знаходяться поруч. Така взаємодія зі світом приводить до усвідомлення того, що людина є найвищою цінністю в світі, метою буття, а не засобом для досягнення певних цілей. Тому визначальним у ставленні до неї $\epsilon$ толерантність і повага. Поруч 3 ціннісними ставленнями, усвідомлення своїх прав i свобод та вміння їх захищати $\epsilon$ запорукою розвитку громадянськості, як інтегральної риси, адже права людини - той інструмент, за допомогою якого вона може відстоювати свої інтереси, втілювати сутнісні сили, тобто те, що є для неї благом. Формування ціннісного ставлення до себе та до інших відбувається саме завдяки вмінню захищати свої права та права інших людей. 
Ціннісне ставлення до Батьківщини i до людства є ознаками громадянськості, що випливають 3 перших двох названих рис. Ставлячись до своєї Батьківщини з ціннісних позицій, особистість поважає свій народ, його мову, історію, звичаї, символіку, гімн; вірить у життєвий потенціал рідної держави; турбується про їі благо і готова завжди захищати національні інтереси.

Важливу роль у структурі ціннісного ставлення відіграють почуття. Лише за умови наявності стійких позитивних переживань відносно Вітчизни стає можливим формування активного ціннісного ставлення до неї. Якщо ж у ставленні до Батьківщини мають місце почуття обурення, байдужості, то ціннісним таке ставлення назвати не можна.

Громадянин, який ціннісно ставиться до Батьківщини, обов'язково цінує й людство в цілому, адже запорукою збереження національних інтересів $\epsilon$ толерантне ставлення до всіх народностей. Толерантність до великих і малих народів - риса, притаманна особистості вільного і демократичного суспільства. Вона проявляється у повазі до прав, свобод, культури, національних особливостей інших народів; здатності вирішувати проблеми з різноманітними етнічними та релігійними групами шляхом компромісу.

Поважаючи інші народи, особистість осягає єдність та унікальність життя на Землі, відчуває себе складовою великого організму, такою ж потрібною та неповторною, як інші. Ціннісне ставлення до людства передбачає співіснування, співтовариство, співпрацю з іншими особистостями на основі принципів справедливості, милосердя, взаємодопомоги.

Значущою ознакою громадянськості є сформованість ціннісного ставлення до природи, яке виявляється в усвідомленні взаємозв'язку людини 3 природою, причетності до всіх природних явищ, охороні та примноженні природних багатств, активній боротьбі з усім, що шкодить навколишньому середовищу. Це стосується не лише оберігання природи рідного краю, своєї Батьківщини, але i планетарного екологічного середовища в цілому.

Висновки та перспективи подальших досліджень. Отже, на нашу думку, патріотичне виховання $є$ складовою громадянського виховання. Побудова громадянського суспільства залежить не тільки від патріотичних почуттів, любові до рідної землі, знання історії, мови, культури, шанобливого ставлення до інших народів, але і від сформованої правової свідомості, соціальнопсихологічної зрілості, коли людина усвідомлює себе активним творцем своєї долі та долі власної держави. Перспективи подальших досліджень полягають у дослідженні ефективних умов для виховання патріотизму через призму громадянського виховання у вищому військовому навчальному закладі.

\section{ЛІТЕРАТУРА}

1. Концепція громадянського виховання особистості в умовах розвитку української державності. Шлях освіти. 2000. №3. 7-13.

2. Національно-патріотичне виховання. Міністерство освіти і науки України. URL: https://mon.gov.ua/ua/osvita/pozashkilna-osvita/vihovna-robota-ta-zahist-prav-ditini/nacionalnopatriotichne-vihovannya (дата звернення: 08.11.2021). 
3. Пашкова О.О. (2021). Військово-патріотичне виховання курсантів вищих військових навчальних закладів України (1991-2019) : автореф. дис. на здобуття наук. ступеня канд. іст. наук : 20.02.22 «Військова історія», Київ, 2021.

\title{
REFERENCES
}

1. Kontseptsiia hromadianskoho vykhovannia osobystosti $\mathrm{v}$ umovakh rozvytku ukrainskoi derzhavnosti [The concept of civic upbringing of the person in the development of Ukrainian statehood]. Shliakh osvity. 2000. №3. 7-13.

2. Natsionalno-patriotychne vykhovannia. Ministerstvo osvity i nauky Ukrainy [Nationalpatriotic upbringing. Ministry of Education and Science of Ukraine]. URL: https://mon.gov.ua/ua/osvita/pozashkilna-osvita/vihovna-robota-ta-zahist-prav-ditini/nacionalnopatriotichne-vihovannya (data zvernennia: 08.11.2021).

3. Pashkova O.O. (2021). Viiskovo-patriotychne vykhovannia kursantiv vyshchykh viiskovykh navchalnykh zakladiv Ukrainy (1991-2019) [Military-patriotic upbringing of cadets of higher military educational institutions of Ukraine (1991-2019)]: avtoref. dys. na zdobuttia nauk. stupenia kand. ist. nauk : 20.02.22 «Viiskova istoriia», Kyiv, 2021.

\section{РЕЗЮМЕ}

Екатерина Трибулькевич доктор педагогических наук, доцент Национальная академия Службы безопасности Украины

\section{К вопросу соотношения гражданского и патриотического воспитания}

В статье рассмотрена сущуность понятия «патриотическое воспитание» и его задачи согласно современной системе национально-патриотического воспитания; определен феномен гражданского воспитания и его компоненты; с помощью методов анализа, синтеза, доказывания, сравнения, абстрагирования, обобщения, конкретизации соотнесены понятия «гражданское воспитание» $u$ «патриотическое воспитание». Ключевые слова: патриотическое воспитание, гражданское воспитание, высшее военное учебное заведение, ценностное отношение к себе, иенностное отношение к другим, ценностное отношение $\kappa$ Родине, ценностное отношение к труду, политическая и правовая культура.

Ключевые слова: патриотическое воспитание; гражданское воспитание; высшее военное учебное заведение; ценностное отношение к себе; ценностное отношение к другим; ценностное отношение к Родине; ценностное отношение к труду; политическая и правовая культура.

\section{SUMMARY}

\author{
Kateryna Trybulkevych \\ doctor of pedagogical sciences, \\ associate professor \\ National Academy of Security \\ Service of Ukraine
}

\section{To the question of the ratio of civic and patriotic upbringing}

Introduction. In the conditions of Russian aggression, temporary occupation of the autonomous republic of Crimea, separate districts of Luhansk and Donetsk regions, along with the issues of our state's defense capability and readiness of Ukrainians to defend their homeland, the issue of patriotic upbringing of children and youth acquires a special sound.

Purpose. Determine the relationship between the concepts of "patriotic upbringing" and 
"civic upbringing".

Methods. The research used methods of analysis, synthesis, proof, comparison, abstraction, generalization, concretization in order to objectively study the phenomena of patriotic and civic upbringing.

Results. Civic education is turned to the personality of the citizen. After all, it is based on the idea of Jean-Jacques Rousseau on the principle of natural law, when the human right to a dignified life, work, conditions for improvement is higher than human laws. Consequently, the state provides decent conditions first, and then requires devotion, observance of the law, service to the people, and the ability to lay down one's life for one's compatriots, which is called patriotism. In addition, civic education involves knowledge of their rights and freedoms and the ability to protect them in a civilized manner, respect for the coat of arms, anthem, symbols, knowledge of native history and culture and their respect.

Patriotic upbringing is a component of civic upbringing. Building a civil society depends not only on patriotic feelings, love for the homeland, knowledge of history, language, culture, respect for other peoples, but also on the formed legal consciousness, socio-psychological maturity, when a person realizes himself an active creator of his destiny and destiny own state. Prospects for further research are to study the effective conditions for the education of patriotism through the prism of civic education in higher military education.

Originality. The article considers the essence of the concept of "patriotic upbringing " and its tasks, according to the modern system of national-patriotic upbringing; the phenomenon of civic upbringing and its components are determined; with the help of methods of analysis, synthesis, proof, comparison, abstraction, generalization, concretization, the concept of "civic upbringing" and "patriotic upbringing" are correlated.

Conclusion. Thus, patriotic upbringing is a component of civic upbringing. Building a civil society depends not only on patriotic feelings, love for the homeland, knowledge of history, language, culture, respect for other peoples, but also on the formed legal consciousness, sociopsychological maturity, when a person realizes himself an active creator of his destiny and destiny own state. Prospects for further research are to study the effective conditions for the upbringing of patriotism through the prism of civic upbringing in higher military education.

Key words: patriotic upbringing; civic upbringing; higher military educational institution; value attitude to oneself; value attitude to others; value attitude to the Motherland; value attitude to work; political and legal culture. 